\title{
Indian university system overhauled
}

Indian universities are likely to find themselves under a new oversight body, human resource development minister Kapil Sibal announced last week.

Physicist Yash Pal led the committee that recommended setting up a six-member National Commission for Higher Education and Research (NCHER) to reform higher education. The commission would replace nearly a dozen regulatory bodies and bring all streams of higher education, including engineering, medicine, agriculture and law, under its purview.

Many Indian scientists welcomed the move, although some are sceptical. Chemist C. N. R. Rao, former science adviser to Prime Minister Manmohan Singh, says that the current infrastructure has led to graduates without the quality to compete on the world stage. India ranks behind such smaller powerhouses as Taiwan, Singapore and South Korea in the number of high-impact scientific papers published.
Adding another regulatory body is unlikely to address such problems, Rao says. "It is fine if it remains just an advisory body," he says. "But if it starts controlling the entire educational sectors from medicine to law, it will be simply weighed down by bureaucracy."

According to the committee's report, the NCHER will create new norms for accrediting universities. Approvals for "deemed" universities, which are aspiring independent institutions wanting university status, will be stopped, and the existing ones must be re-accredited. India's deemed universities have mushroomed in recent years, to 123 in total. The report also proposes bolstering funding of state universities and encourages recruitment of foreign faculty.

Pushpa Bhargava, a biologist and founder of the Centre for Cellular and Molecular Biology in Hyderabad, says the recommendations "should be implemented seriously". As an example of shoddy accreditation, he says he has been approached by a private college that asked to borrow academic staff on a short-term basis so that it could have professors on hand for a three-day visit from regulatory body the All India Council for Technical Education. That council, along with others, would be subsumed under the new commission.

Sibal said the recommendations would be implemented within 100 days. The NCHER's chairman will be appointed by President Pratibha Patil, and its members selected by a search committee that will include the prime minister and the leader of the opposition.

"It is a very good thing that has happened for educational reform," Mamannamana Vijayan, president of the Indian National Science Academy, told Nature. "We now need to turn to the question of how to reform the structure of Indian science."

K. S. Jayaraman 